\title{
NEURAL-NETWORK-BASED APPROACH FOR PREDICTION OF THE FIRE RESISTANCE OF CENTRICALLY LOADED COMPOSITE COLUMNS
}

\author{
Marijana Lazarevska, Meri Cvetkovska, Ana Trombeva Gavriloska, Miloš Knežević, Milivoje Milanović
}

Original scientific paper The use of the neural-network-based approach, as an unconventional approach for solving complex civil engineering problems, has a huge significance in the modernization of the construction design processes. Worldwide studies show that artificial neural networks can be successfully used as prognostic model in different engineering fields, especially in those cases where some prior (numerical or experimental) analyses were already made. This paper presents some of the positive aspects of their application for determination the fire resistance of centrically loaded steel-concrete composite columns exposed to fire from all sides. The analyses were performed for three different types of composite columns: totally encased, partially encased and hollow steel sections filled with concrete. The influence of the shape, the cross sectional dimensions and the intensity of the axial force to the fire resistance of centrically loaded composite columns were analysed using the program FIRE. The results of the performed numerical analyses were used as input parameters for training the neural network model which is capable for predicting the fire resistance of centrically loaded composite columns.

Keywords: civil engineering; composite columns; fire resistance; neural network

\section{Primjena umjetnih neuronskih mreža za predviđanje vatrootpornosti centrično opterećenih kompozitnih stupaca}

Izvorni znanstveni članka

Studije koje su dosad sprovedene pokazuju da se umjetne neuronske mreže mogu uspješno koristiti kao prognostički model u različitim inženjerskim područjima, posebice u onim slučajevima u kojima već postoje prethodna istraživanja i analize (numerički ili pokusni). U ovom radu prikazani su neki od pozitivnih aspekata njihove primjene za određivanje vatrootpornosti centrično opterećenih kompozitnih stupova od betona i čelika, izloženih vatri sa svih strana. Analize su provedene na tri različite vrste kompozitnih stupova: potpuno ubetonirani čelični profil, djelomično ubetoniranih čelični profil i šuplji profil od čelika ispunjen betonom. Utjecaj oblika, dimenzije presjeka i intenziteta aksijalne sile na požarnu otpornost centrično opterećenih kompozitnih stupova analizirani su pomoću programa FIRE. Rezultati provedenih numeričkih analiza korišteni su kao ulazni parametri za treniranje modela neuronske mreže koji je prilagođen za predviđanje vatrootpornosti centrično opterećenih kompozitnih stupova.

Ključne riječi: građevinarstvo; kompozitni stup; neuronske mreže; vatrootpornost

\section{Introduction}

Construction Products Directive 89/106/EEC gives the following essential requirement for the limitation of fire risks: The construction works must be designed and built in such a way, that in case of fire the load bearing resistance of the construction can be assumed for a specified period of time, the generation and spread of fire and smoke within the works are limited, the spread of fire to neighbouring construction works is limited, the occupants can leave the works or can be rescued by other means and the safety of rescue teams is taken into consideration [1].

Fire resistance is ability of a structure, a part of a structure or a member to fulfill its required functions (load bearing function and/or fire separating function) for a specified load level, for a specified fire exposure and for a specified period of time [1]. The legally prescribed fire resistance of a structure or structural element depends on: the height and number of flats, the floor area, capacity, content and purpose of the structure, the distance of the fire stations and fire brigades, as well as on the fire protection system of the structure [2].

Most codes recognize that structural design for fire conditions is conceptually similar to structural design for normal temperature conditions. The main differences of fire design compared with normal temperature design are that at the time of a fire: the applied loads are less; internal forces may be induced by thermal expansion; strengths of materials may be reduced by elevated temperatures; cross section areas may be reduced by charring or spalling; smaller safety factors can be used because of the low likelihood of the event; deflections may be important as they may affect strength and global stability; different failure mechanisms need to be considered [2].

According to structural Eurocodes, there are three levels of specifying design for fire performance: tabulated data; simplified calculation methods and advanced calculation models. The three possible levels of analysis of structural behavior are: single member analysis; analysis of sub-assemblage or part of the structure and global structural analysis of the whole structure $[1,2]$.

Most of the Structural Eurocodes include the following statement: "A full analytical procedure for structural fire design would take into account the behavior of the structural system at elevated temperatures, the potential heat exposure and the beneficial effects of active and passive fire protection systems, together with the uncertainties associated with these three features and the importance of the structure (consequences of failure). At the present time it is possible to undertake a procedure for determining adequate performance which incorporates some, if not all, of these parameters and to demonstrate that the structure, or its components, will give adequate performance in a real building fire."

For the last twenty years, particular importance has been given to analytical definition of the problem, but the need for getting answers to many questions in this field implies the application of new, modern and faster, but not less accurate methods for determining the fire resistance of structures. The application of neural networks as such a method for building a prognostic model which can be used for predicting the fire resistance for structural 
members is of a huge importance for the design process in construction $[3,4,5]$.

\section{Neural-network-based approach for determination of the fire resistance of steel-concrete composite columns}

\subsection{Fire resistance of composite columns}

A steel-concrete composite column is a compression member, comprising either a concrete encased steel section or a concrete filled tubular steel section and is generally used as a load-bearing member in a composite framed structure. In a composite column both the steel and concrete would resist the external loading by interacting together by bond and friction. Supplementary reinforcement in the concrete encasement prevents excessive spalling of concrete both under normal load and fire conditions. The concrete and steel are combined in such a way that the advantages of both materials are utilized effectively in composite column $[1,6]$.

Due to the thermal mass of concrete, composite columns always possess a higher fire resistance than corresponding steel columns. It may be recalled that composite columns were actually developed for their inherent high fire resistance. Composite columns are usually designed in the normal or 'cool' state and then checked under fire conditions. Some general rules on the structural performance of composite columns in fire are summarized as follows [6]:

- The fire resistance of composite columns with fully concrete encased steel sections may be treated in the same way as reinforced concrete columns. The steel is insulated by an appropriate concrete cover and light reinforcement is also required in order to maintain the integrity of the concrete cover.
- For composite columns with partially concrete encased steel sections, the structural performance of the columns is very different in fire, as the flanges of the steel sections are exposed and less concrete acts as a 'heat shield'. Additional reinforcement is often required to achieve more than one hour fire resistance.

- For concrete filled tubular sections subjected to fire, the steel sections are exposed to direct heating while the concrete core behaves as 'heat sink'. In general, sufficient redistribution of stress occurs between the hot steel sections and the relatively cool concrete core, so that a fire resistance of one hour can usually be achieved. For longer periods of fire resistance, additional reinforcement is required, which is not provided in normal design.

This paper presents the numerically achieved results for the fire resistance of centrically loaded steel-concrete composite columns with different cross sections, as: concrete filled hollow steel section CFS, partially encased steel section PES and totally encased section TES (Fig.1). For comparison a reinforced concrete column (RC) has also been analysed (as reference one) because it has high fire performance.

The columns with fixed-pinned support conditions and exposed to standard fire ISO 834 from all four sides were analysed by using the computer program FIRE (Fire Response) [2]. The influence of the shape of the cross section (different types of cross sections), cross sectional dimensions $(30 \times 30,30 \times 50$, and $40 \times 40)$ and the intensity of the axial force were analysed. The axial load ratio, which is the ratio between the applied axial force $N$ and the ultimate force $N_{\mathrm{u}}$, was varied from 0,1 to 0,5 .
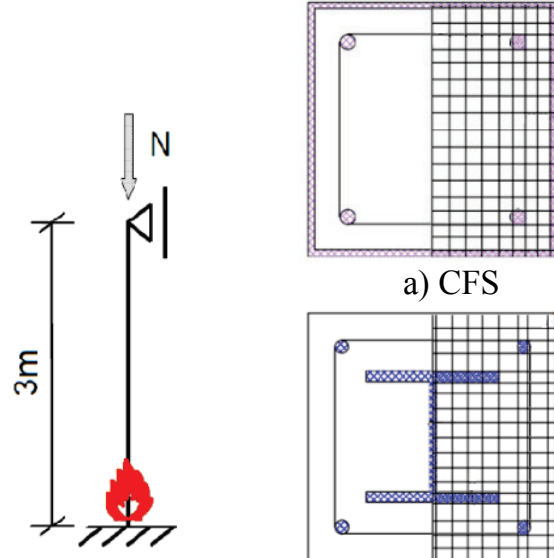

a) CFS



c) TES



b) PES

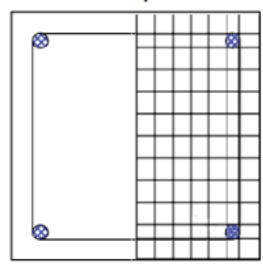

d) $\mathrm{RC}$

Figure 1 Geometry and support conditions, discretization and cross section geometry of the analysed composite columns: a) concrete filled hollow steel section CFS, b) partially encased steel section PES, c) totally encased section TES d) reinforced concrete section $\mathrm{RC}$ (for comparison)

At the beginning, when the peripheral parts of the section are more heated than the interior parts, Fig. 2a, in the heart of the section cracked zones appear, Fig. 2b (TES30). The heated parts tend to expand, but because of the restrained dilatation by the cold parts of the cross section, in the heart of the sections tensile stresses occur. The lower the axial load ratio is, the more expressed the phenomenon is. In time, the temperature penetrates into the sections, the temperature differences are smaller and the cracks are closed. The reason for closing the cracks is the reduction of the mechanical properties of steel and concrete caused by temperature, therefore, the compression stresses caused by the axial force 
compensate the tensile stresses caused by the temperature differences $[2,3,6]$.

Highest fire resistance has the totally encased section while the partly encased section and the concrete filled hollow section have lower fire resistance (Fig. 3). The steel profiles significantly increase the initial bearing capacity of the partly encased sections and the concrete filled hollow sections, but, because of the peripheral position of the steel it is heated to high temperatures in relatively short time period and the reduction of the mechanical properties of steel is caused, which results in lower fire resistance.
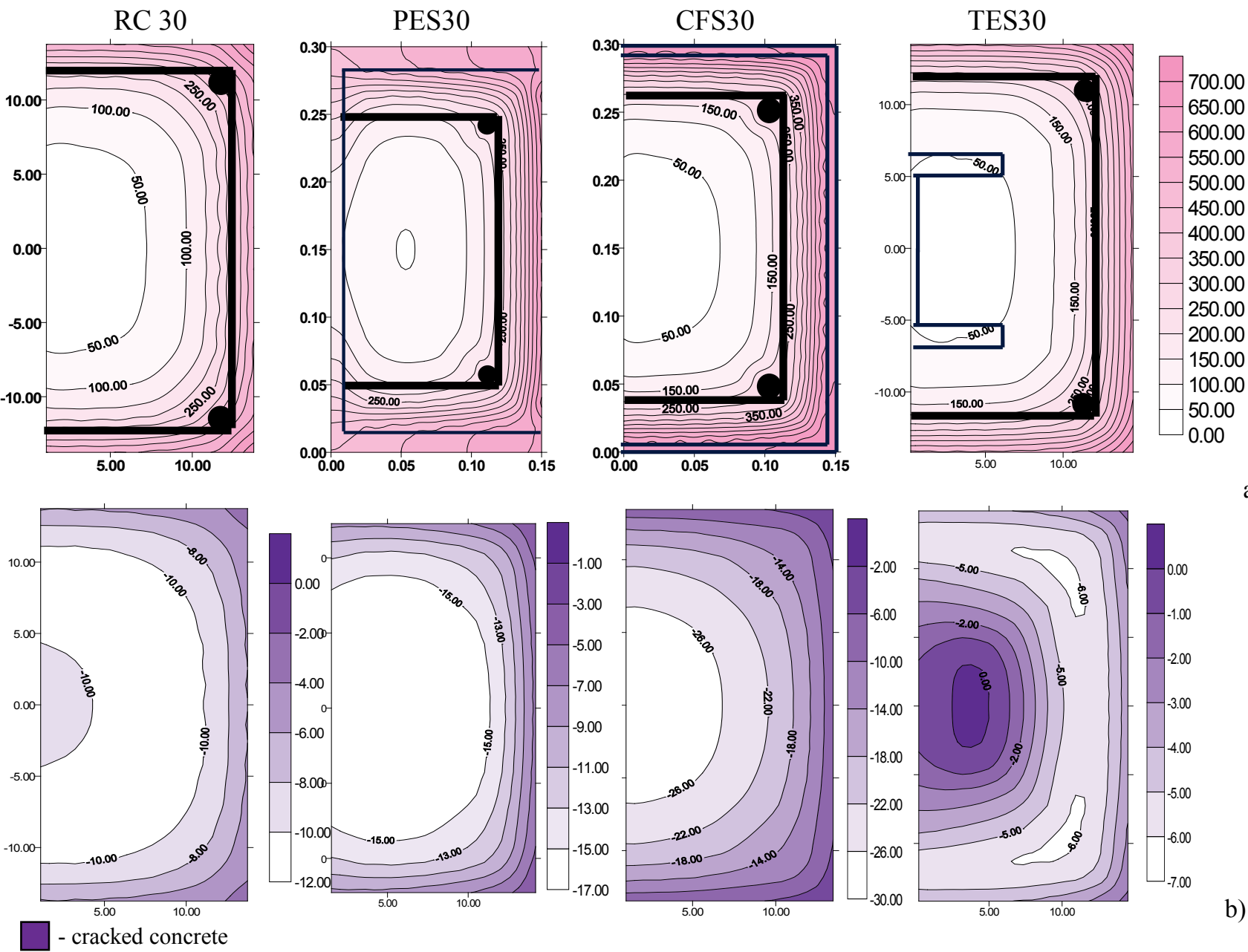

a)

Figure 2 a) Isotherms, b) Isobars in cross section of columns at moment $t=1,0$ hour, for axial load ratio $\alpha=0,3$

For an axial load ratio from 0,1 to 0,3 , which is a very common case in practice, the fire resistance of these sections is approximately $50 \%$ of the fire resistance of the totally encased section.

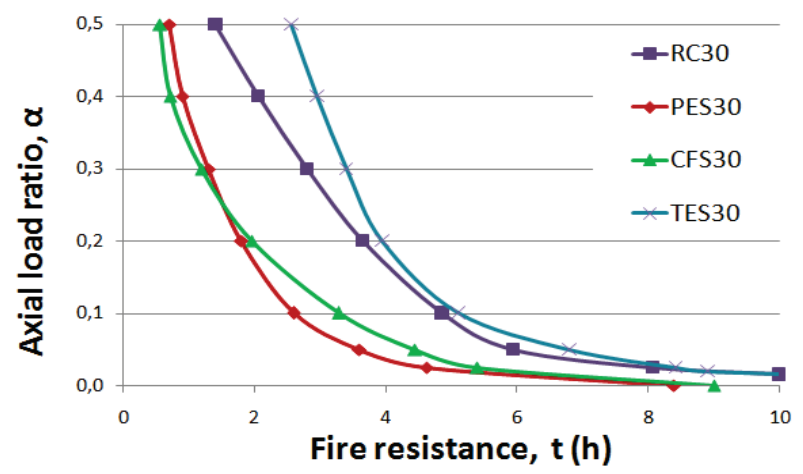

Figure 3 Influence of type of the cross section on fire resistance of composite steel-concrete columns

The steel profile of the totally encased section is in the interior part of the section and it is protected by the concrete that has a low thermal conductivity, which provides the steel to stay cold for a longer period of time and keep its mechanical properties which provides higher fire resistance. Additional disadvantage of the partly encased section, in terms of fire resistance, is the proportional participation of the steel section which is higher than the one in the concrete hollow section; therefore, the partly encased section has higher ultimate strength for service conditions. If the axial load ratio $\alpha$ is the same for both partly encased section and concrete hollow section, the axial force has higher value for the partly encased section and in case of fire it has to be accepted by the concrete core, therefore the partly encased section has lower fire resistance than the concrete hollow section.

Evidently, the cross section dimensions, more precisely the area of the cross section, directly affects the heat capacity of the section, and therefore has significant influence on the fire resistance. The bigger the dimensions are, the slower the section is heated, achieving higher fire resistance (Fig. 4). 
There is an exception for the partly encased section. In this case the section with $40 \times 40 \mathrm{~cm}$ has lower fire resistance than the one with $30 \times 50 \mathrm{~cm}$. The reason, in this case, is the fact that in the section with $40 \times 40 \mathrm{~cm}$ the steel profile participates with $25,6 \%$ in the cross section area, while in the section with $30 \times 50 \mathrm{~cm}$ only 17 $\%$, therefore, after the strength reduction of the steel profile, the concrete section is more loaded than the one in the section with $40 \times 40 \mathrm{~cm}$, giving it a lower fire resistance.
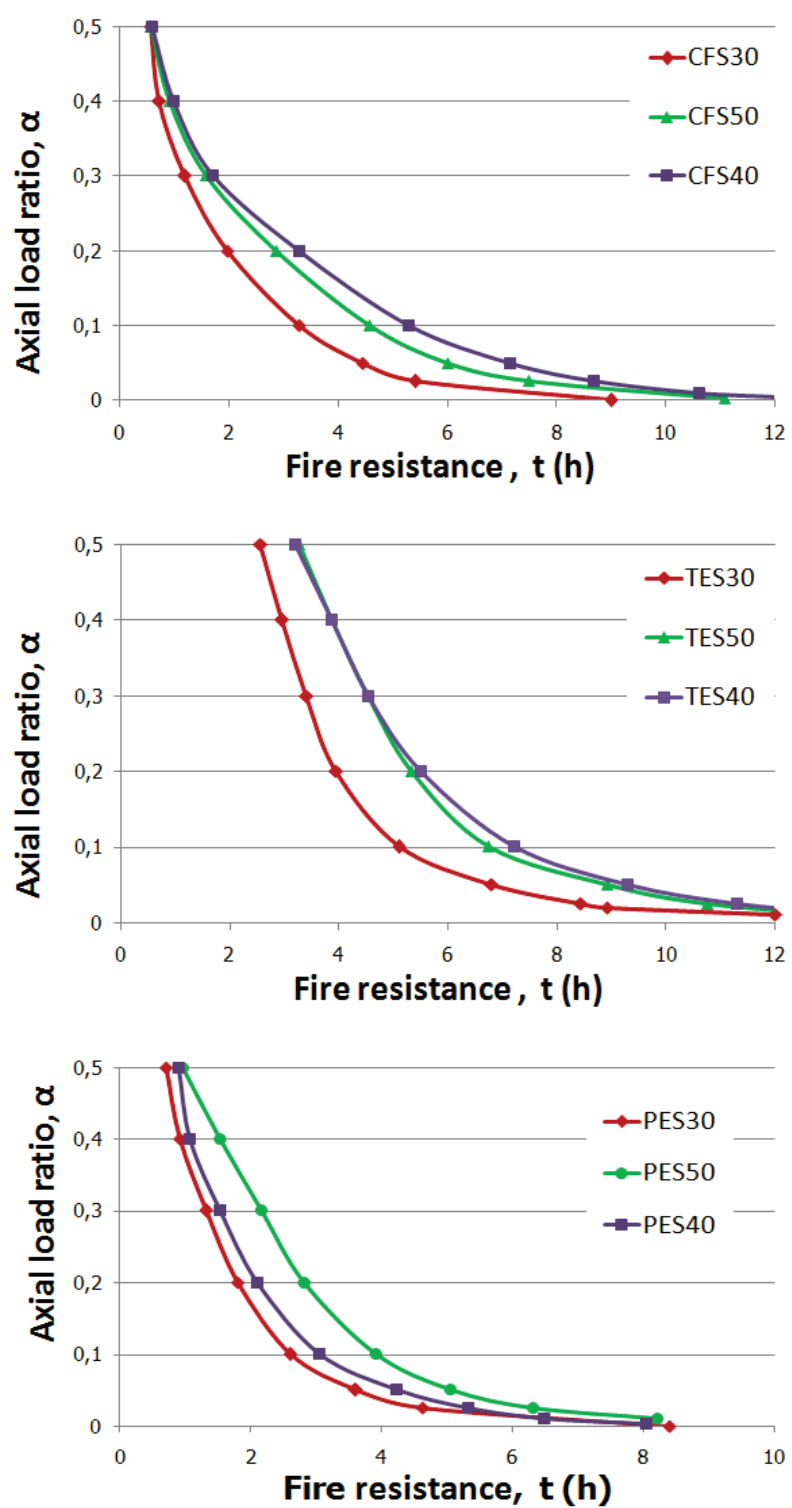

Figure 4 Influence of the cross sectional dimensions on fire resistance of composite steel-concrete columns

\subsection{Neural network prognostic model}

Using the results obtained by the performed numerical analyses, the goal of this paper was to build a neural network model which can predict the fire resistance of centrically loaded steel-concrete composite columns with different cross sections. The numerical results were used as input data in order to create and train the neural network so it can provide precise outputs for the fire resistance of composite concrete columns for any other input data.
The neural network was developed, trained and tested using the software Neural Tools ver. 6. Total of 87 cases, input-output data, were analysed, out of which 70 cases $(80 \%)$ were used for the training of the neural network while the rest of 17 cases $(20 \%)$ were used for testing of the network's precision.

In order to find the optimal neural network nine multi-layered neural networks (MLFN) with forward propagation were trained and tested. Training and testing of the neural networks is an iterative process that repeats the procedure of training and testing of several neural networks with different structures until it generates a neural network which provides the best outcomes $[7 \div 12]$.

The network architecture consisted of three layers: one input layer, one hidden layer and one output layer, with different number of neurons in the hidden layer ( 2 to 10 neurons). The input layer of the neural network had four neurons, one neuron for each independent variable: dimensions of the cross section of the columns ( $a$ and $b$ ), loading coefficient $(\alpha)$ and the type of the composite columns. The loading coefficient represents the ratio between the applied axial force and the ultimate axial force.

Four different types of composite columns were analysed: concrete filled hollow steel sections CFS, partially encased steel sections PES, totally encased steel sections TES and reinforced concrete sections RC, as reference ones. The output layer had only one variable: the fire resistance of the column expressed in minutes $(t)$.

All nine multi-layered neural networks were trained through 1000000 learning cycles. For the multi-layered networks with spreading the information forward (in one direction, from input to output layer) the learning cycle means determination of weight coefficients for the connections between neurons, where the training process is a smart choice of weight coefficients that give the best predictions $[8 \div 13]$. Training stops at the moment when the error between the actual output (numerically obtained value) and the predicted output (value obtained by the neural network model) reaches the defined error value [5].

The trained multi-layered neural networks were tested in order to check their prediction accuracy. The assessment of their prediction accuracy was done by comparing the following three parameters: percentage of bad predictions, value of the root mean square error (RMSE) and value of the mean absolute error (MAE). If the percentage of bad predictions is within the allowable limits (less than $30 \%$ ), then the optimal neural network is the network that has the lowest value of the root mean square error and mean absolute error obtained by testing [5].

The results from the testing of the analysed 9 neural networks show that the multi-layered network with 7 neurons in hidden layer gives the lowest prediction error. The value of the RMSE for the MLFN with 7 neurons in the hidden layer was 0,35, while the value of the MAE was 0,27 . Therefore this type of architecture is adopted as the optimal for determination the fire resistance of analysed composite columns.

The comparison between the predicted values, obtained by the trained neural network, and the numerically obtained values, for the fire resistance of the 
analysed composite columns, expressed in hours, is given in Fig. 5.

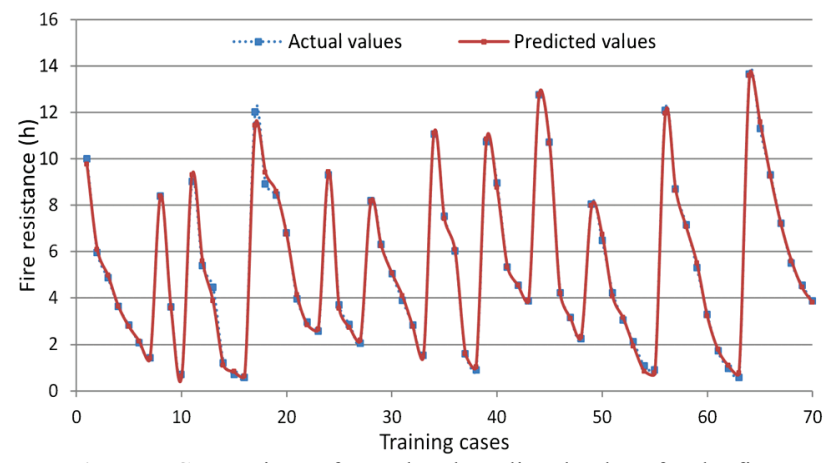

Figure 5 Comparison of actual and predicted values for the fire resistance of composite columns, used for training of the neural network

The results shown in this figure, for all 70 training cases, demonstrate that the neural network prognostic model can generate very precise values for the fire resistance of steel-concrete columns exposed to fire from all four sides.

The trained neural network was tested in order to check the network quality and prediction accuracy. The testing was performed by using 17 data groups different from the data used in the training process. Those 17 testing cases were not used in the process of learning and training of the model. The predicted values obtained by the trained neural network for the testing cases and the corresponding numerically obtained values, are compared in Fig. 6. The testing and comparison of the obtained numerical values for the time of fire resistance of steelconcrete columns gave excellent results.

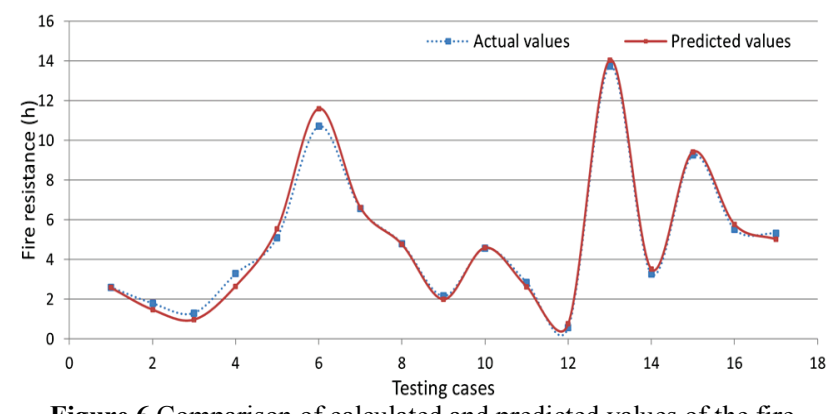

Figure 6 Comparison of calculated and predicted values of the fire resistance of composite columns, used for testing the neural network

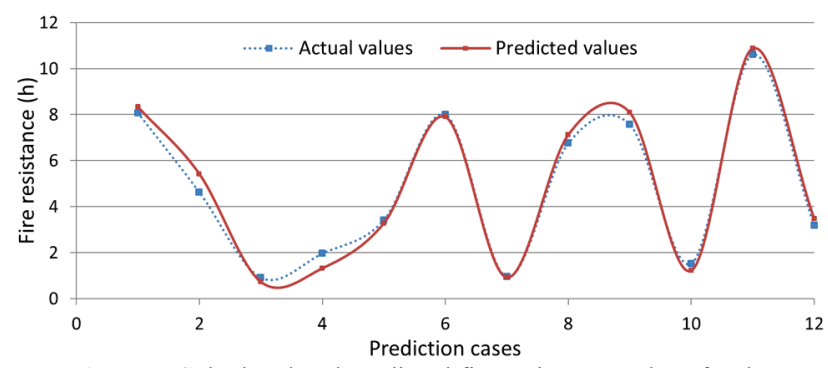

Figure 7 Calculated and predicted fire resistance values for the prediction cases, cases that were not included in the training and testing process

The comparison of the actual values (obtained by the numerical analyses) and the predicted fire resistance values (obtained by the neural network prognostic model) for 12 cases that were not included in the training and testing process, is graphically presented in Fig. 7.
Based on the results obtained from the numerical analysis and the neural network prognostic model, fire resistance curves were constructed. These curves may be used for determination of the fire resistance of composite steel concrete columns that were not previously analysed. The fire resistance curves for the columns with dimensions $30 \times 30 \mathrm{~cm}$ and different types of cross section, constructed by both methods, are presented in Fig. 8. From these curves, depending on the level of the axial force (load coefficient $\alpha$ ) and the type of the cross section, the fire resistance of the column could be defined without any additional calculation.

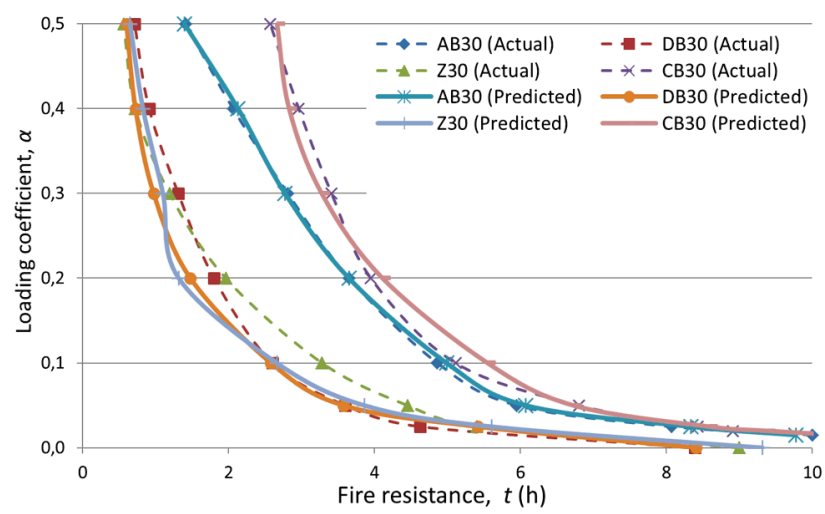

Figure 8 Comparison of calculated (actual) and predicted fire resistance curves for centrically loaded composite columns with cross section dimensions $30 \times 30 \mathrm{~cm}$

It can be seen that the corresponding curves constructed on the basis of the numerically achieved results and on the basis of the results from the neural network approach are similar and give close results. This was the main goal of this research: to explain the simplicity and the positive aspects of the usage of the neural networks for solving engineering problems. After the comparison of both methods it can be concluded that artificial neural networks present an excellent tool for prognostic modelling and can be used for determination of the fire resistance of reinforced concrete columns, especially in those cases when there are no (or very few) experimental and/or numerical results.

\section{Conclusions}

The fire resistance of a structure can be determined based on the estimated fire resistance of each construction element (columns, beams, slabs, walls etc.). The fire resistance of a structural element is the time period (in minutes) from the beginning of the fire until the moment when the element reaches its ultimate capacity (ultimate strength, stability and deformability) or until the element loses the insulation and separation function [1].

The legally prescribed fire resistance can be achieved through different constructive or passive measures (proper form, element's dimensions and static system) or with some active measures (thermo isolation etc.). There are various protection measures and their choice depends mainly on the type of construction material that needs to be protected. Different construction materials (concrete, steel, wood) have different behaviour under higher temperatures so they have to be treated in accordance with their individual characteristics when exposed to fire 
$[1,2]$. Even though the legally prescribed fire resistance is of huge importance for the quality and safety of every structure, in Macedonia there is still no specific legally binding regulation for the fire resistance. The official national codes in the Republic of Macedonia are not upgraded, and the creation of new codes is still an ongoing process.

The application of neural networks for prognostic modelling which can be used for predicting the fire resistance of structural members is of huge importance for the construction design process and at the same time could help in upgrading the national codes for fire resistance of structures. Most of the experimental models for determination of fire resistance are extremely expensive, and analytical models are quiet complicated and time consuming. That is why a modern type of analyses, such as modelling through neural networks, can help, especially in those cases where some prior analyses were already made.

\section{References}

[1] EN1994-1-2: Eurocode 4 - Design of composite steel and concrete structures, Part 1-2: General rules - Structural fire design,2005.

[2] Cvetkovska, M. Nonlinear stress strain behaviour of RC elements and plane frame structures exposed to fire. // Ph. D thesis, Civil Engineering Faculty in Skopje, Sts Cyril and Methodius University, Macedonia, 2002.

[3] Lazarevska, M.; Knezevic, M.; Cvetkovska, M.; Trombeva, G. A.; Samardzioska, T. Neural network's application for predicting the fire resistance of reinforced concrete columns. // Gradjevinar. 7, (2012), pp. 565-571.

[4] Lazarevska, M.; Trombeva, G. A.; Knezevic, M.; Samardzioska, T.; Cvetkovska, M. Neural network prognostic model for RC beams strengthened with CFRP strips. // Applied Engineering Science. 10, (2012), pp. 2730.

[5] http://www.palisade.com/neuraltools/

[6] Long, T. P.; McAllister, T. P.; Gross, J. L.; Hurley, M. J, Best Practice Guidelines forStructural Fire Resistance Designof Concrete and Steel Buildings. // NIST Technical Note 1681,2010

[7] Chen, A. M.; Lu, H.-M.; Hecht-Nielsen, R. On the geometry of feed forward neural network error surfaces.// Proceedings of Neural computations, 1993, pp. 910-927.

[8] Flood, I.; Nabil, K. Neural networks in civil engineering II: Systems and application. // Computing in Civil Engineering. 8, 2(1994), pp. 149-162. DOl: 10.1061/(ASCE)0887-3801(1994)8:2(149)

[9] Flood, I.; Paul, C. Modeling construction processes using artificial neural networks. // Automation in Construction. 4, 4(1996), pp. 307-320. DOI: 10.1016/0926-5805(95)00011-9

[10] Flood, I. Simulating the construction process using neural networks // Proceedings of the 7th ISARC - International Association for Automation and Robotics in Construction / Bristol, 1990, pp. 374-382.

[11] Jeng, D. S.; Cha, D. H.; Blumenstein, M. Application of Neural Networks in Civil Engineering Problems // Proceedings of the International Conference on Advances in the Internet, Processing, Systems and Interdisciplinary Research, 2003.

[12] Knežević, M. Risk management of civil engineering projects. // $\mathrm{PhD}$ thesis Civil Engineering Faculty, University in Belgrade, Serbia, 2005.

[13] Knežević, M.; Zejak, R. Neural networks - application for usage of prognostic model of the experimental research for thin reinforced-concrete columns. // Materials and constructions, 2008.

\section{Authors' addresses}

Marijana Lazarevska, PhD

Faculty of Civil Engineering

Partizanski odredi 24, 1000 Skopje, Macedonia

E-mail: marijana@gf.ukim.edu.mk

Meri Cvetkovska, PhD

Faculty of Civil Engineering

Partizanski odredi 24, 1000 Skopje, Macedonia

E-mail: cvetkovska@gf.ukim.edu.mk

Ana Trombeva Gavriloska, PhD

Faculty of Architecture

Partizanski odredi 24, 1000 Skopje, Macedonia

E-mail: agavriloska@arh.ukim.edu.mk

Milos Knezevic, PhD

Faculty of Civil Engineering

Cetinjski put b.b., Podgorica, Montenegro

E-mail: knezevicmilos@hotmail.com

Milivoje Milanović, MSc

State University of Novi Pazar, Serbia

E-mail: pbarhisnp@gmail.com 